\title{
Trichomes that secrete substances of a mixed nature in the vegetative and reproductive organs of some species of Moraceae
}

\author{
Bruna Noce Schnetzler', Simone Pádua Teixeira' and Cristina Ribeiro Marinho1*
}

Received: August 11, 2016

Accepted: December 12, 2016

\begin{abstract}
This study aimed to obtain new information about the distribution, morphology and content of secretory trichomes present in the vegetative and reproductive organs of four species of Moraceae: Artocarpus heterophyllus, Dorstenia cayapia, Maclura tinctoria and Sorocea bonplandii. Stem, leaf, flower and inflorescence samples were processed for scanning electron and light microscopy. The species have secretory trichomes on the leaf blade, petiole and stem and also on the inflorescence and flowers of D. cayapia and S. bonplandii and on the peduncle of the inflorescence in $A$. heterophyllus. These trichomes are of the capitate type in all species, but A. heterophyllus also possess peltate secretory trichomes. Both trichome types exhibit a multicellular head and a unicellular peduncle. Peduncle size and head cell number varies according to species. Peltate trichomes located in depressions were found only in species of Artocarpus, and so should be of diagnostic value for the genus. In all species the trichomes secrete polysaccharides, alkaloids and lipids; phenolic compounds occur in A. heterophyllus and M. tinctoria trichomes. These trichomes probably act in the protection against herbivores, pathogens, desiccation and/ or UV radiation. Moreover, the trichomes found in the inflorescence of $D$. cayapia may exert a function in pollen grain adhesion.
\end{abstract}

Keywords: anatomy, Artocarpus, Dorstenia, flower, gland, leaf, Maclura, morphology, Sorocea

\section{Introduction}

Trichomes are appendages of protodermal origin with a variable structure that can be found in the vegetative and reproductive organs of plant species. They are classified as unior pluricellular, sessile or pedunculated, secretory (glandular) or non-secretory, as scales, papillae and absorbent hairs (Esau 1974). Secretory trichomes are of special interest by producing substances originating from the special metabolism of plants such as oils, nectar, salts, resins, mucilage, digestive juices, and water among others, depending on the species and the need of the plant. These trichomes consist of a unicellular or multicellular head of different shape and size present on the upper extremity. In sessile trichomes, the head is directly connected to the surface of the plant, while in pedunculated trichomes this connection occurs by means of a peduncle that may be uni- or multicellular and of variable size (Fahn 1979; Castro \& Machado 2012). In the urticalean rosid families (Cannabaceae, Moraceae, Ulmaceae and Urticaceae) (Sytsma et al. 2002) the secretory trichomes show a diverse morphology and are classified as spherical or capitate, elongated or filiform, clavate, peltate or called sunken glands, with a variable number of cells in the head and peduncle (Shah \& Kachroo 1975; Gangadhara \&

\footnotetext{
${ }^{1}$ Departamento de Ciências Farmacêuticas, Faculdade de Ciências Farmacêuticas de Ribeirão Preto, Universidade de São Paulo, Av. do Café, s/n., 14040-903, Ribeirão Preto, SP, Brazil
}

* Corresponding author: crm.botanica@gmail.com 
Inamdar 1977; Tobe \& Takaso 1996). The study of Gangadhara \& Inamdar (1977) stands out, as the authors elaborated a morphological classification for the secretory trichomes based on analyses of the leaves of various species of this group.

Since secretory trichomes vary widely in morphology, no relations have been detected between their morphology and the substances they produce (Fahn 1979; Dickison 2000). This means that different trichomes may secrete similar substances and the same morphological trichome may secrete different substances in different species or organs. Some of the compounds secreted by plants have medicinal properties and are used in the composition of natural products and drugs by the pharmaceutical industry (Filho \& Yunes 1998; Jagtap \& Bapat 2010).

Moraceae, the family of mulberries and figs, consists of 40 genera with approximately 1,200 species divided into six tribes: Artocarpeae, Castilleae, Dorstenieae, Ficeae, Maclureae and Moreae (Clement \& Weiblen 2009; The Plant List 2013). According to Metcalfe \& Chalk (1950) secretory trichomes commonly occur in the leaves of species of this family and have been reported in Artocarpus sp. (Artocarpeae), Broussonetia sp., Dorstenia sp., Fatoua sp., Brosimum gaudichaudii (Dorstenieae), Ficus sp. (Ficeae), Maclura tinctoria (Maclureae), Morus sp., Sorocea bonplandii and Streblus asper (Moreae) (Shah \& Kachroo 1975; Gangadhara \& Inamdar 1977; Tobe \& Takaso 1996; Wu \& Kuo-Huang 1997; Jacomassi \& Machado 2003; Jacomassi et al. 2007; Munir et al. 2011; Duarte et al. 2012). In the organs involved in reproduction, secretory trichomes have been detected in the bracts and peduncle of the inflorescence of Brosimum gaudichaudii (Jacomassi et al. 2010), along the syconium of Ficus species (Machado et al. 2013; Souza et al. 2015) and in the sepals and hypantium (flower and fruit) of Sorocea bonplandii (Souza \& Rosa 2005).

The scarcity of reports of secretory trichomes in the reproductive organs of Moraceae indicates that few anatomical studies of the floral secretory structures of this family have been conducted, with researchers being more interested in those occurring in the vegetative body, probably because of easier collection. In addition, studies about the secretory content of trichomes in Moraceae were performed only for Brosimum gaudichaudii (Jacomassi et al. 2007; 2010) and Ficus (Machado et al. 2013; Souza et al. 2015), in which the authors observed the presence of lipids, polysaccharides and/ or phenolic compounds in the trichome exudate. In Ficus species these trichomes seem to act in the organ lubrication or in the protection against herbivores and UV radiation (Machado et al. 2013; Souza et al. 2015). No functions were raised for the secretory trichomes found in B. gaudichaudii.

In view of the economic importance of Moraceae for the food industry, the production of wood, ornamentation (Judd et al. 2009) or folk medicine (Lorenzi \& Matos 2002; Ustulin et al. 2009; Jagtap \& Bapat 2010) and considering that secretory trichomes are related to the medicinal properties of plant species (Gobbo-Neto \& Lopes 2007), this is an interesting group to be used as a model for the study of secretory trichomes and even of floral glands.

Thus, the objective of the present study was to compare the distribution, morphology and exudate of the secretory trichomes present in the vegetative and reproductive aerial organs of four Moraceae species belonging to different tribes of the family: Artocarpus heterophyllus (Artocarpeae), Dorstenia cayapia (Dorstenieae), Maclura tinctoria (Maclureae) and Sorocea bonplandii (Moreae). The purpose was to increase our knowledge about these trichomes in Moraceae, by associating the organ occurrence and chemical nature of the trichome exudate with its role in this plant group.

\section{Materials and methods}

The species Artocarpus heterophyllus Lam., Dorstenia cayapia Vell. and Maclura tinctoria (L.) D.Don ex Steud. were collected in Ribeirão Preto, SP, Campus of the University of São Paulo, while Sorocea bonplandii (Baill.) W.C.Burger, Lanj. \& de Boer was collected in Viçosa, MG, Campus of the Federal University of Viçosa. Voucher specimens were deposited in the SPFR herbarium under numbers C.R.Marinho 01 and 02 for M. tinctoria, C.R.Marinho 03 for S. bonplandii, C.R.Marinho 04 for A. heterophyllus, and C.R.Marinho 05 and V.G.Leite 02 for D. cayapia.

Stem branches, leaf, flower and inflorescence samples of A. heterophyllus, D. cayapia and M. tinctoria, and stem and leaf samples of $S$. bonplandii were collected, fixed in buffered formalin (Lillie 1965) or in Karnovsky solution (Karnovsky 1965) for $24 \mathrm{~h}$, dehydrated and stored in $70 \%$ alcohol. S. bonplandii flower and inflorescence samples were obtained from the collection of the VIC herbarium (accession numbers P.P. de Souza 266 and 267), submitted to the process of herborization reversal (Smith \& Smith 1942) and dehydrated and stored in $70 \%$ alcohol. At least two individuals per species were investigated.

The external morphology of the trichomes was studied by scanning electron microscopy (SEM), and the inner morphology of the trichomes and their content was studied by light microscopy (LM). These analyzes were performed in stems in primary structure and initial secondary structure, in expanding leaves and in inflorescences containing anthetic flowers.

For SEM analysis, fixed samples were reduced to $1 \mathrm{~cm}^{2}$, dehydrated in an increasing ethanol series and dried to the critical $\mathrm{CO}_{2}$ point with a Bal Tec CPD030 drier. The samples were mounted on metal supports and sputtered with gold using a Bal Tec SCD050 sputter coater. The images were analyzed and captured with a Jeol JSM 6610LV scanning electron microscope.

For the LM study, samples were dehydrated in an ethanol series, embedded in metacrylate (Historesin, Leica) and cut into crosswise and lengthwise 3-5 $\mu \mathrm{m}$ thick sections with a rotary microtome (Leica RM2245). The material was 
stained with $0.05 \%$ toluidine blue (O'Brien et al. 1964) for the general study of the cells that compose the secretory trichomes and for the detection of phenolic compounds, with periodic acid-Schiff (PAS) (Jensen 1962) for the detection of polysaccharides, with ruthenium red (Johansen 1940) for the detection of pectins, and with xylidine Ponceau (Vidal 1970) for the detection of proteins. Part of the material stored in alcohol was cut with the aid of a table microtome and stained with Sudan III and Sudan black B (Pearse 1985) for the detection of lipids, with ferric chloride (Johansen 1940) for the detection of phenolic compounds, and with Wagner's reagent (Furr \& Mahlberg 1981) for the detection of alkaloids. Photomicrographs were obtained with a Leica DM 4500 B photomicroscope coupled with a Leica DFC 295 digital camera using scales in the same optical conditions.

\section{Results}

\section{Distribution}

The four species have a greater quantity of secretory trichomes on both surfaces of the leaf blade and a smaller quantity on the stem and petiole. In the reproductive organs the secretory trichomes are found on the inflorescences (peduncle, axis of inflorescence) and flowers (floral pedicel, hypanthium, sepals, filaments) of Dorstenia cayapia and Sorocea bonplandii and on the peduncle of the inflorescences of Artocarpus heterophyllus (see Tab. 1, Figs. 1, 2). No trichomes are found on the flower and inflorescence of Maclura tinctoria.

\section{Morphology}

Artocarpus heterophyllus show capitate and peltate secretory trichomes, which are located in depressions of the organs where they occur. They are 38-40 $\mu \mathrm{m}$ long, and while the peltate trichomes have six cells in the head arranged in a radial shape (Fig. 2A), the capitate trichomes present eight cells, having four in the upper part and four in the lower part of the head (Fig. 2B-C). In both trichome types, the peduncle is short and unicellular, 10-12 $\mu \mathrm{m}$ long and has thickened anticlinal and inner periclinal walls. Trichome-cystoliths (Fig. 1B) are also observed among the secretory trichomes.

In Dorstenia cayapia the secretory trichomes are of the capitate type and are located in depressions on both surfaces of the leaf blade and at the same level as neighboring cells in the remaining organs. Their length ranges from 24 to $27 \mu \mathrm{m}$ for the inflorescences and from 28 to $32 \mu \mathrm{m}$ for the leaf. They consist of two cells in the head and one in the peduncle, which is procumbent and 13-17 $\mu \mathrm{m}$ long, with thickened anticlinal walls (Fig. 2D-E).

The secretory trichomes of Maclura tinctoria and Sorocea bonplandii are also capitate and are located at the same level as neighboring cells in all organs where they occur. They have eight cells in the head (four in the upper region and four in the lower region) and a procumbent unicellular peduncle with thickened anticlinal walls. In $M$. tinctoria the secretory trichomes measure $36-44 \mu \mathrm{m}$ in total length, with a 15-20 $\mu \mathrm{m}$ peduncle. The secretory trichomes of $S$. bonplandii measure $43-50 \mu \mathrm{m}$, with a peduncle ranging in length from 20 to $24 \mu \mathrm{m}$ (Fig. 2F-I).

\section{Histochemistry}

The secretory trichomes of the species studied here are lined with a cuticle that reacts with Sudan III and black B and contain an exudate consisting of hydrophilic and lipophilic substances. Both the cells of the head and of the peduncle of the trichome are secretory and their exudate contains polysaccharides, alkaloids and lipids in all species. Phenolic compounds were also detected in the secretory trichomes of Artocarpus heterophyllus and Maclura tinctoria (Tab. 2, Figs. $3,4)$. These substances are observed in the cytoplasm and/ or vacuole of the trichome cells, while lipids also occur in the subcuticular space of the trichome in all species (Tab. 2).

Table 1. Secretory trichome distribution on Moraceae species. + = presence; - = absence, 0 = not applicable (D. cayapia has underground stem and pistillate flower without perianth), $a b=$ abaxial surface, $\mathrm{ad}=$ adaxial surface.

\begin{tabular}{|c|c|c|c|c|}
\hline Structure & $\begin{array}{c}\text { Artocarpus } \\
\text { heterophyllus }\end{array}$ & $\begin{array}{c}\text { Dorstenia } \\
\text { cayapia }\end{array}$ & $\begin{array}{l}\text { Maclura } \\
\text { tinctoria }\end{array}$ & $\begin{array}{c}\text { Sorocea } \\
\text { bonplandii }\end{array}$ \\
\hline Leaf & $\begin{array}{c}\text { + (petiole and blade: ad/ab) } \\
\text { (Figs. 1A, 2A-C) }\end{array}$ & $\begin{array}{c}\text { + (petiole and blade: ad/ab) } \\
\text { (Figs. 1C, 2D) }\end{array}$ & $\begin{array}{c}+ \text { (petiole and blade: ad/ab) } \\
\quad \text { (Figs. 1E, 2F) }\end{array}$ & $\begin{array}{c}\text { + (petiole and blade: ad/ab) } \\
\text { (Figs. 1F, 2G-H) }\end{array}$ \\
\hline Stem & + & 0 & + & $\stackrel{+}{+}$ \\
\hline Pistillate inflorescence & $\begin{array}{l}+ \text { (peduncle) } \\
\quad \text { (Fig. 1B) }\end{array}$ & $\begin{array}{c}\text { + (peduncle and inflorescence } \\
\text { axis) (Fig. 2E) }\end{array}$ & - & $\begin{array}{c}+ \text { (peduncle and } \\
\text { inflorescence axis) }\end{array}$ \\
\hline Staminate inflorescence & + (peduncle) & $\begin{array}{c}\text { + (peduncle and inflorescence } \\
\text { axis) (Fig. 1D) }\end{array}$ & - & $\begin{array}{c}+ \text { (peduncle and } \\
\text { inflorescence axis) }\end{array}$ \\
\hline Pistillate flower & - & 0 & - & $\begin{array}{l}\text { + (flower pedicel, hypanthium } \\
\text { and sepals: ab) (Figs. 1H, 2I) }\end{array}$ \\
\hline Staminate flower & - & + (sepals: $\mathrm{ad} / \mathrm{ab}$ and fillets) & - & $\begin{array}{c}+ \text { (flower pedicel and sepals: } \\
\mathrm{ab})\end{array}$ \\
\hline
\end{tabular}



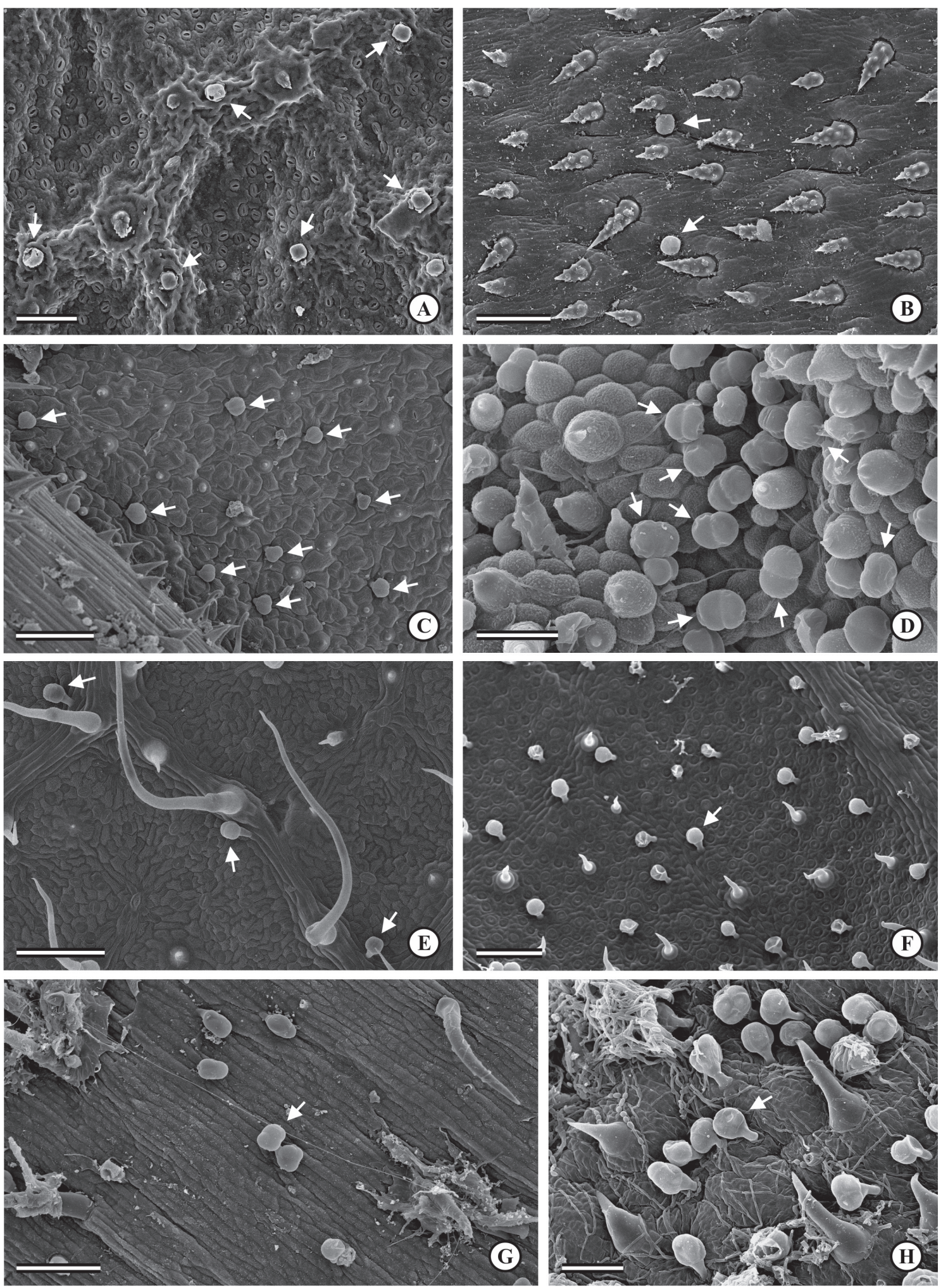

Figure 1. Scanning electron micrographs of the distribution of trichomes on the different organs of the Moraceae studied species. A-B: Artocarpus heterophyllus. A: Secretory trichomes on the abaxial surface of the leaf blade. B: Secretory trichomes among the trichome-cystoliths on the peduncle of the pistillate inflorescence. C-D: Dorstenia cayapia. C: Secretory trichomes on the abaxial surface of the leaf blade. D: Secretory trichomes among the papillae on the axis of the staminate inflorescence. E: Maclura tinctoria. Secretory trichomes concentrated on the ribs along the abaxial surface of the leaf blade. F-H: Sorocea bonplandii. F: Several secretory trichomes along the abaxial surface of the leaf blade. G: Secretory trichomes on the stem surface. H: Secretory trichomes among the non-glandular trichomes on the abaxial surface of the pistillate flower sepals. White arrows = secretory trichomes. Bars: $100 \mu \mathrm{m}$ (A-C, E-G); $40 \mu \mathrm{m}(\mathrm{D}) ; 50 \mu \mathrm{m}(\mathrm{H})$. 

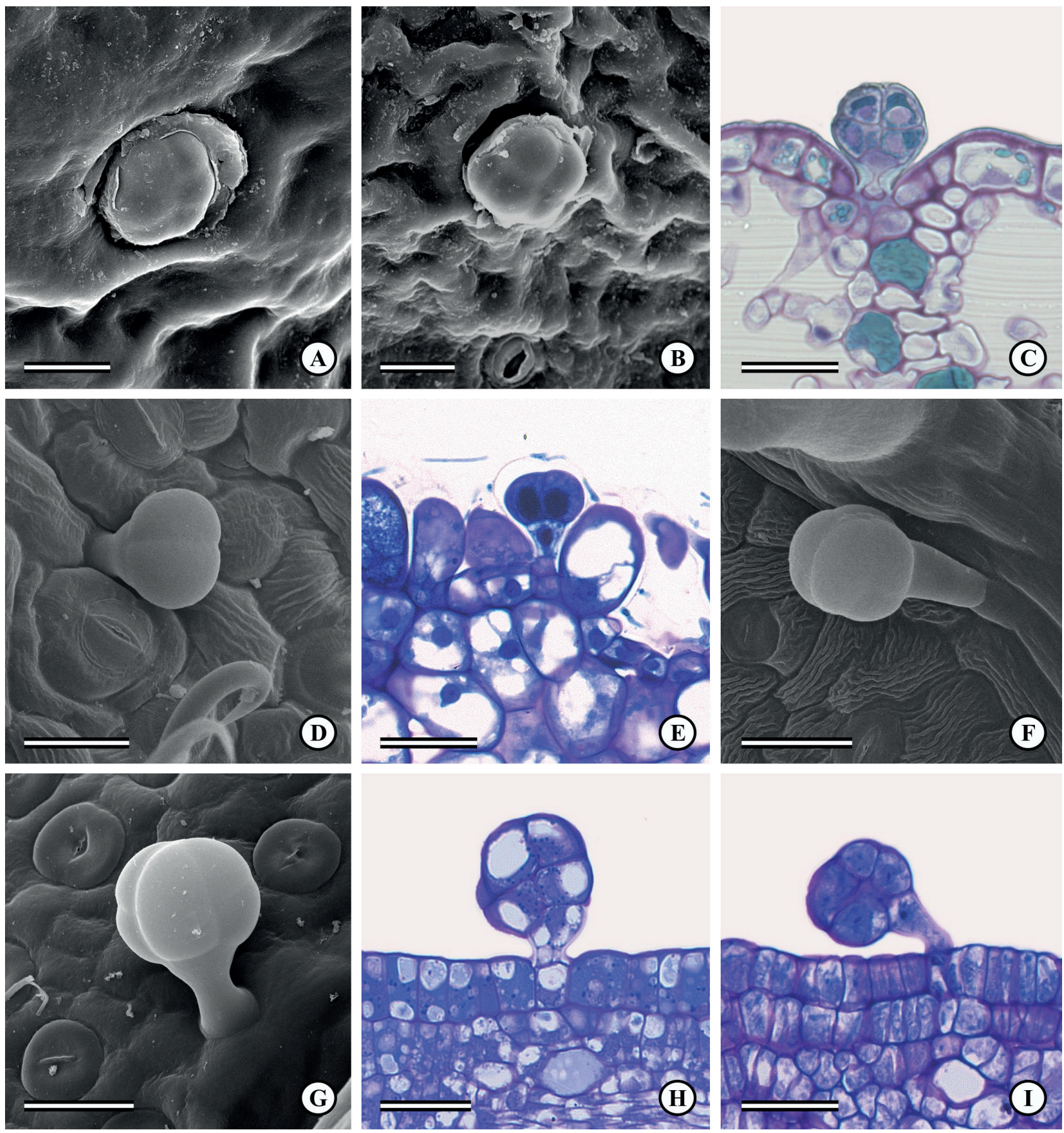

Figure 2. Scanning electron micrographs (A, B, D, F, G) and photomicrographs (C, E, H, I - staining: toluidine blue) of the trichomes of the Moraceae studied species. A-C: Artocarpus heterophyllus. A: Secretory trichome on the adaxial surface of the leaf blade with the head formed by six cells arranged radially. B-C: Secretory trichomes on the abaxial surface of the blade with a head composed of eight cells. In C, also note the trichome located in a depression showing a unicellular peduncle with thickened anticlinal and inner periclinal walls. D-E: Dorstenia cayapia. D: Secretory trichome on the abaxial surface of the leaf blade with a unicellular peduncle and a two-celled head. E: Secretory trichome on the axis of the pistillate inflorescence. F: Maclura tinctoria. Secretory trichome on the abaxial surface of the leaf blade showing a unicellular peduncle and a four-celled head. G-I: Sorocea bonplandii. G-H: Secretory trichomes on the abaxial $(G)$ and adaxial $(\mathrm{H})$ surfaces of the leaf blade consisting of a unicellular peduncle and a four-celled head. I: Secretory trichome on the abaxial surface of the pistillate flower sepals showing a procumbent peduncle. Bars: $20 \mu \mathrm{m}(\mathrm{A}, \mathrm{B}, \mathrm{D}, \mathrm{F}, \mathrm{G}), 30 \mu \mathrm{m}(\mathrm{C}, \mathrm{E}, \mathrm{H}, \mathrm{I})$. 
It is interesting to note that in Dorstenia cayapia there were variations between the content of the trichomes present on leaves and on inflorescences, with no polysaccharides being detected in the foliar trichomes (Tab. 2). In the trichomes on inflorescence, polysaccharides are observed in the cell cytoplasm and vacuole, whereas in the pistillate inflorescences in special such class of substance also occurs in the trichome subcuticular space.

Among the tests used, the more expressive reactions were for phenolic compounds, polysaccharides and alkaloids (Tab. 2, Figs. 3A-F, 4A-G). The lipids detected in the secretory trichome head occur in the form of very small droplets (Fig. 4H). However, the anticlinal cell walls of the trichome peduncle of all species strongly reacted with Sudan, indicating the presence of lipids in these regions (Fig. 4I). The proteins found in the trichome cells are observed in the nucleus and cytoplasm, which indicates that they are part of the cellular metabolism of the trichome and do not compose the exudate.

\section{Discussion}

The trichomes detected in the vegetative and reproductive organs of Artocarpus heterophyllus, Dorstenia cayapia and Sorocea bonplandii and in the vegetative organs of Maclura tinctoria have a similar general morphology (they are small and consist of a multicellular head and a unicellular peduncle), a fact that may be related to the phylogenetic proximity of these species (see Clement \& Weiblen 2009).

The secretory trichome of the capitate type observed in all the species studied seems to be the most common for the family, being present in various genera of Moraceae (see Metcalfe \& Chalk 1950; Shah \& Kachroo 1975;

Table 2. Results of the histochemical tests performed in the secretory trichomes of Moraceae species sampled in this study. The cell regions that have positively reacted with the reagents are indicated in parentheses. ${ }^{*}$ The identification of alkaloids was not conclusive in A. heterophyllus due to their natural color which is similar to the positive staining with the Wagner reagent.

\begin{tabular}{|c|c|c|c|c|c|c|c|}
\hline \multirow{2}{*}{ SPECIES } & \multicolumn{2}{|c|}{ Phenolic compounds } & \multirow{2}{*}{$\begin{array}{c}\text { Polysaccharides } \\
\text { PAS }\end{array}$} & \multirow{2}{*}{\begin{tabular}{|c|} 
Pectins \\
ruthenium red
\end{tabular}} & \multirow{2}{*}{\begin{tabular}{|c|} 
Proteins \\
xylidine Ponceau
\end{tabular}} & \multirow{2}{*}{$\begin{array}{c}\text { Alkaloids } \\
\text { Wagner reagent }\end{array}$} & \multirow{2}{*}{\begin{tabular}{|c|} 
Lipids \\
Sudan III/ black B
\end{tabular}} \\
\hline & Toluidine blue & ferric chloride & & & & & \\
\hline $\begin{array}{l}\text { A. heterophyllus } \\
\text { Leaf }\end{array}$ & $\begin{array}{l}++(\text { vacuole }) \\
\quad(\text { Fig. } 2 \mathrm{C})\end{array}$ & $\begin{array}{c}++ \text { (cytoplasm, } \\
\text { vacuole) } \\
\text { (Fig. 3A) }\end{array}$ & $\begin{array}{l}++ \text { (nucleus, } \\
\text { cytoplasm, } \\
\text { vacuole, wall) } \\
\quad(\text { Fig. } 3 C)\end{array}$ & $\begin{array}{l}\text { + (nucleus, } \\
\text { cytoplasm, wall) } \\
\text { (Fig. } 3 G)\end{array}$ & $\begin{array}{c}\text { +(nucleus, } \\
\text { cytoplasm) } \\
\text { (Fig. 4A) }\end{array}$ & $\begin{array}{l}+{ }^{*} \text { (nucleus, } \\
\text { cytoplasm, } \\
\text { vacuole) }\end{array}$ & $\begin{array}{l}\text { + (cytoplasm, } \\
\text { subcuticular } \\
\text { space, cuticle, } \\
\text { peduncle wall) }\end{array}$ \\
\hline $\begin{array}{l}\text { D. cayapia } \\
\text { Leaf }\end{array}$ & - & - & + (wall) & $\begin{array}{l}+ \text { (nucleus, } \\
\text { cytoplasm, wall) }\end{array}$ & $\begin{array}{l}\text { +(nucleus, } \\
\text { cytoplasm) } \\
\text { (Fig. 4B) }\end{array}$ & $\begin{array}{l}++ \text { (nucleus, } \\
\text { cytoplasm) }\end{array}$ & $\begin{array}{l}\text { + (cytoplasm, } \\
\text { subcuticular } \\
\text { space, cuticle, } \\
\text { peduncle wall) }\end{array}$ \\
\hline $\begin{array}{c}\text { D. cayapia } \\
\text { Staminate } \\
\text { inflorescence }\end{array}$ & - & - & $\begin{array}{c}++ \text { (nucleus, } \\
\text { cytoplasm, } \\
\text { vacuole, wall) }\end{array}$ & $\begin{array}{c}\text { + (nucleus, } \\
\text { cytoplasm, } \\
\text { vacuole, wall) }\end{array}$ & $\begin{array}{l}\text { + (nucleus, } \\
\text { cytoplasm) }\end{array}$ & $\begin{array}{l}++ \text { (nucleus, } \\
\text { cytoplasm) }\end{array}$ & $\begin{array}{l}\text { + (cytoplasm, } \\
\text { subcuticular } \\
\text { space, cuticle, } \\
\text { peduncle wall) }\end{array}$ \\
\hline $\begin{array}{c}\text { D. cayapia } \\
\text { Pistillate inflorescence }\end{array}$ & - & - & $\begin{array}{l}++ \text { (nucleus, } \\
\text { cytoplasm, } \\
\text { vacuole, wall, } \\
\text { subcuticular } \\
\text { space) } \\
\text { (Fig. 3D) }\end{array}$ & $\begin{array}{l}\text { + (nucleus, } \\
\text { cytoplasm, } \\
\text { vacuole, wall, } \\
\text { subcuticular } \\
\text { space) } \\
\text { (Fig. } 3 \mathrm{H})\end{array}$ & $\begin{array}{l}\text { + (nucleus, } \\
\text { cytoplasm) }\end{array}$ & $\begin{array}{c}++ \text { (nucleus, } \\
\text { cytoplasm) } \\
\text { (Fig. } 4 \mathrm{E})\end{array}$ & $\begin{array}{l}\text { + (cytoplasm, } \\
\text { subcuticular } \\
\text { space, cuticle, } \\
\text { peduncle wall) } \\
\text { (Fig. } 4 \mathrm{H})\end{array}$ \\
\hline $\begin{array}{l}\text { M. tinctoria } \\
\text { Leaf }\end{array}$ & - & $\begin{array}{c}++(\text { cytoplasm }) \\
\quad(\text { Fig. 3B })\end{array}$ & $\begin{array}{l}\text { ++ (nucleus, } \\
\text { cytoplasm, } \\
\text { vacuole, wall) } \\
\quad \text { (Fig. } 3 E)\end{array}$ & $\begin{array}{c}\text { + (nucleus, } \\
\text { cytoplasm, } \\
\text { vacuole, wall) }\end{array}$ & $\begin{array}{l}\text { +(nucleus, } \\
\text { cytoplasm) } \\
\text { (Fig. } 4 \text { C) }\end{array}$ & $\begin{array}{c}++ \text { (nucleus, } \\
\text { cytoplasm, } \\
\text { vacuole) } \\
\text { (Fig. 4F) }\end{array}$ & $\begin{array}{c}\text { + (cytoplasm, } \\
\text { subcuticular } \\
\text { space, cuticle, } \\
\text { peduncle wall) } \\
\text { (Fig. } 4 \mathrm{I})\end{array}$ \\
\hline $\begin{array}{l}\text { S. bonplandii } \\
\text { Leaf }\end{array}$ & - & - & $\begin{array}{c}++ \text { (nucleus, } \\
\text { cytoplasm, } \\
\text { vacuole, wall) }\end{array}$ & $\begin{array}{l}+ \text { (nucleus, } \\
\text { cytoplasm, wall) } \\
\text { (Fig. 3I) }\end{array}$ & $\begin{array}{l}\text { + (nucleus, } \\
\text { cytoplasm) }\end{array}$ & $\begin{array}{c}++ \text { (nucleus, } \\
\text { cytoplasm, } \\
\text { vacuole) } \\
\text { (Fig. } 4 \mathrm{G})\end{array}$ & $\begin{array}{l}\text { + (cytoplasm, } \\
\text { subcuticular } \\
\text { space, cuticle, } \\
\text { peduncle wall) }\end{array}$ \\
\hline $\begin{array}{l}\text { S. bonplandii } \\
\text { Staminate } \\
\text { inflorescence }\end{array}$ & - & - & $\begin{array}{c}\text { ++ (nucleus, } \\
\text { cytoplasm, } \\
\text { vacuole, wall) }\end{array}$ & $\begin{array}{l}\text { + (nucleus, } \\
\text { cytoplasm, wall) }\end{array}$ & $\begin{array}{l}\text { + (nucleus, } \\
\text { cytoplasm) }\end{array}$ & $\begin{array}{l}++ \text { (nucleus, } \\
\text { cytoplasm, } \\
\text { vacuole) }\end{array}$ & $\begin{array}{l}\text { + (cytoplasm, } \\
\text { subcuticular } \\
\text { space, cuticle, } \\
\text { peduncle wall) }\end{array}$ \\
\hline $\begin{array}{c}\text { S. bonplandii } \\
\text { Pistillate inflorescence }\end{array}$ & - & - & $\begin{array}{l}++ \text { (nucleus, } \\
\text { cytoplasm, } \\
\text { vacuole, wall) } \\
\quad \text { (Fig. 3F) }\end{array}$ & $\begin{array}{l}+ \text { (nucleus, } \\
\text { cytoplasm, wall) }\end{array}$ & $\begin{array}{c}\text { + (nucleus, } \\
\text { cytoplasm) } \\
\text { (Fig. 4D) }\end{array}$ & $\begin{array}{l}++ \text { (nucleus, } \\
\text { cytoplasm, } \\
\text { vacuole) }\end{array}$ & $\begin{array}{l}\text { + (cytoplasm, } \\
\text { subcuticular } \\
\text { space, cuticle, } \\
\text { peduncle wall) }\end{array}$ \\
\hline
\end{tabular}



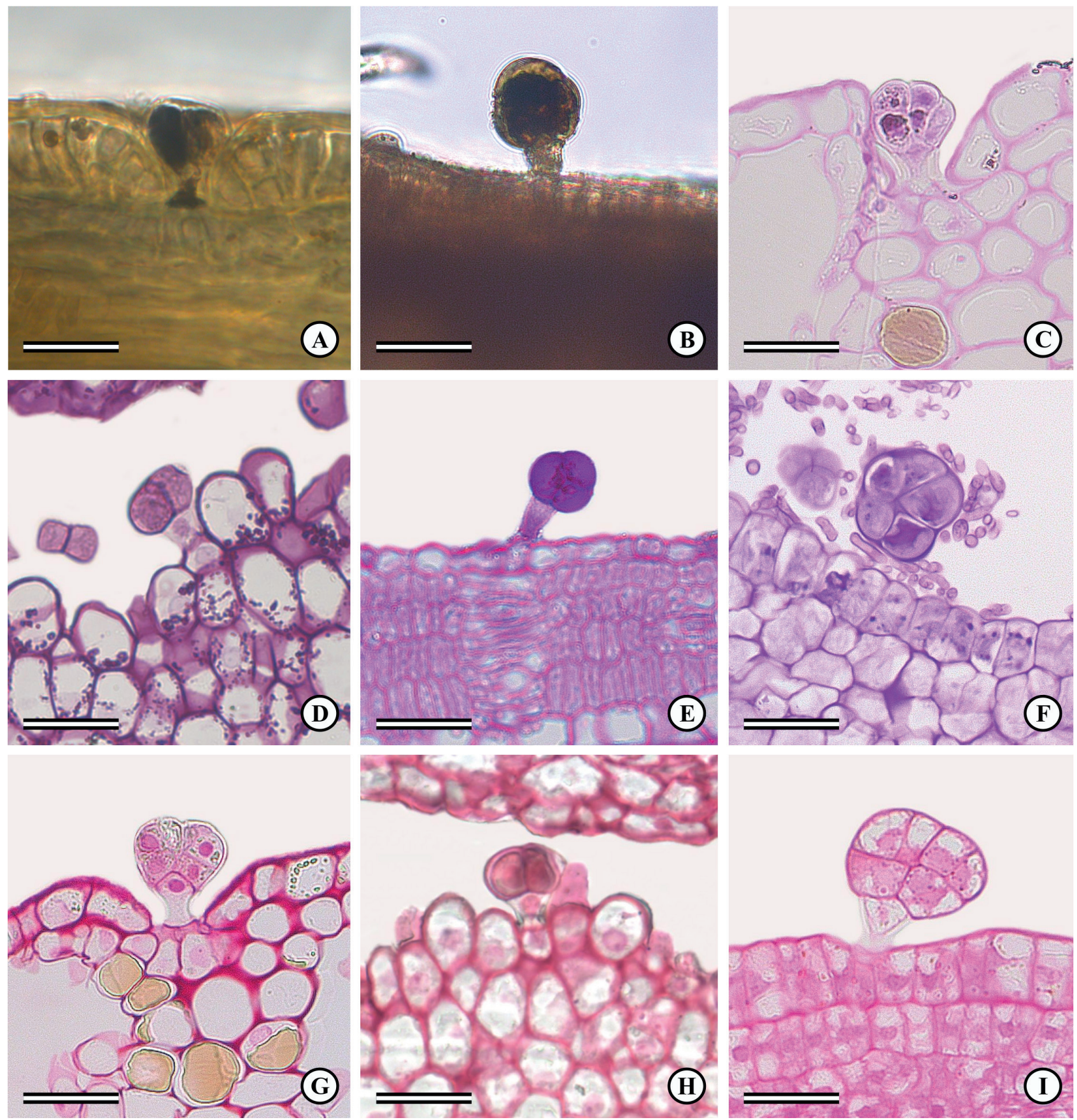

Figure 3. Photomicrographs of the secretory trichomes of the Moraceae studied species (staining: A-B - ferric chloride, C-F - periodic acid-Schiff, G-I - ruthenium red). A-B: Trichome with phenolic content on the leaf of Artocarpus heterophyllus (A) and Maclura tinctoria (B). C-F: Trichome with polysaccharides on the leaf of A. heterophyllus (C), on the axis of the pistillate inflorescence of Dorstenia cayapia (D), on M. tinctoria leaf (E) and on the pistillate flower sepal of Sorocea bonplandii (F). G-I: Trichome with pectic content on the leaf of A. heterophyllus (G), on the axis of the pistillate inflorescence of D. cayapia (H) and on S. bonplandii leaf (I). Bars: $30 \mu \mathrm{m}$.

Gangadhara \& Inamdar 1977; Tobe \& Takaso 1996). In contrast, the trichome of the peltate type arranged in depressions detected in Artocarpus heterophyllus, seems to be a unifying characteristic for the genus Artocarpus since it was observed on the leaves of other species such as A. altilis, A. lacucha and A. incisa (Shah \& Kachroo 1975; Gangadhara \& Inamdar 1977; Wu \& Kuo-Huang 1997; Martínez 2008).
It is important to note that peltate trichomes although not located in depressions were already reported for Brosimum gaudichaudii (Jacomassi et al. 2007; 2010) and Broussonetia papyrifera (Shah \& Kachroo 1975).

In addition to capitate and peltate types, there are other classifications in the literature for these trichomes in representatives of Moraceae, such a spherical for species 

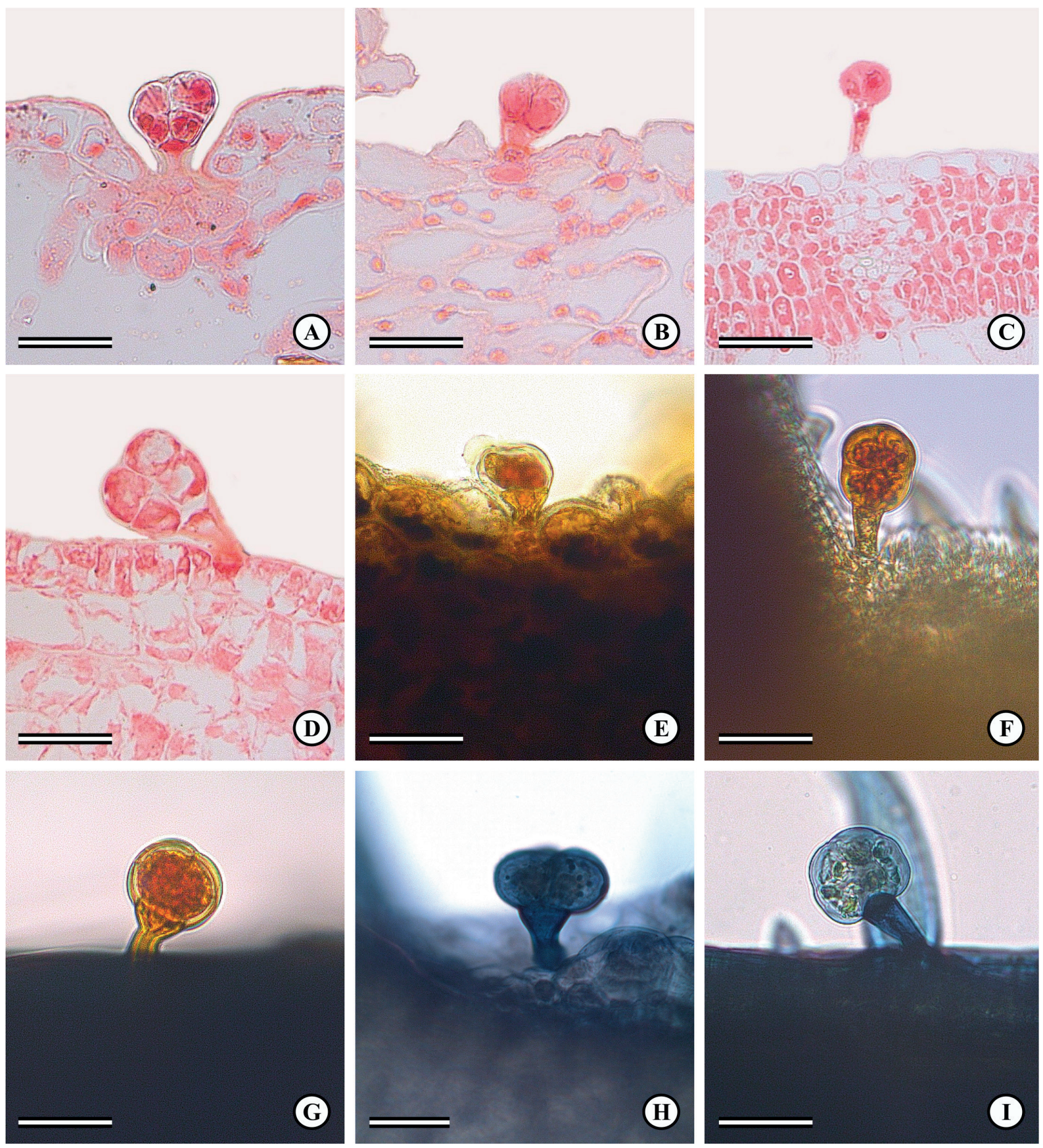

Figure 4. Photomicrographs of the trichomes of the Moraceae studied species (staining: A-D - xylidine Ponceau, E-G - Wagner reagent, H-I - Sudan black B). A-D: Trichome with protein content on the leaf of Artocarpus heterophyllus (A), Dorstenia cayapia (B) and Maclura tinctoria (C) and on the axis of the pistillate inflorescence of Sorocea bonplandii (D). E-G: Trichome with alkaloid content on the axis of the pistillate inflorescence of D. cayapia (E) and on the leaf of $M$. tinctoria (F) and S. bonplandii (G). H: Trichome containing lipid droplets on the axis of the pistillate inflorescence of $D$. cayapia. I: Lipid compounds in the wall of the trichome peduncle of $M$. tintoria. Bars: $30 \mu \mathrm{m}(\mathrm{A}-\mathrm{G}, \mathrm{I}) ; 10 \mu \mathrm{m}(\mathrm{H})$.

of Morus, Streblus asper and Broussonetia papyrifera, elongated for species of Ficus and Morus (Shah \& Kachroo 1975) and clavate for Broussonetia kazinoki, Cudrania tricuspidata (= Maclura tricuspidata), Dorstenia contrajerva,
Fatoua villosa, Ficus erecta and Morus bombycis (= Morus australis) (Tobe \& Takaso 1996). We believe that spherical trichomes correspond to capitate tichomes, while elongated trichomes correspond to the filiform trichomes according 
to the classification of Gangadhara \& Inamdar (1977). In addition, the short and long clavate trichomes described by Tobe \& Takaso (1996) probably also correspond to the filiform trichomes.

The present study demonstrates that the distribution of secretory trichomes in the organs of Moraceae is more extensive than reported in the literature. Capitate secretory trichomes have already been described for the stem, petiole, leaf blade (abaxial surface) and pistillate flowers (sepals and hypanthium) of Sorocea bonplandii (Jacomassi \& Machado 2003; Souza \& Rosa 2005). Our findings expand the distribution of these structures to the adaxial surface of the leaf, to the pistillate and staminate inflorescences, to the pedicel of pistillate flowers and to the pedicel and sepals of staminate flowers of this species. In A. heterophyllus, peltate trichomes have already been reported for the leaf blade (Martínez 2008) and also occur in the stem, petiole and peduncle of pistillate and staminate inflorescences. In addition, the present study also revealed the presence of capitate trichomes in these species organs. However, for Dorstenia cayapia, this is the first report of secretory trichomes, while for the genus Dorstenia there are only anatomical descriptions of secretory trichomes for the leaves of D. contrajerva and D. indica (Gangadhara \& Inamdar 1977; Tobe \& Takaso 1996) and for the axis of inflorescence of D. arifolia and D. bonijesu (Araújo 2008). It is interesting to note the presence of secretory trichomes only in the aerial vegetative organs of Maclura tinctoria (present study, Duarte et al. 2012).

The wide distribution of secretory trichomes in the vegetative and reproductive organs of Artocarpus heterophyllus, Dorstenia cayapia and Sorocea bonplandii and in the vegetative organs of Maclura tinctoria indicates their ecological importance for these species. The multiple functions attributed to the secretory trichomes depend on their location in the plant, on the chemical nature of their exudate and on the environment where the plant species grow (Fahn 1979; 2000; 2002; Press 1999). They may be related to leaf protection against phytophagous, to reflect solar radiation, to maintain the leaf temperature, to avoid loss of water and to pollinator attraction, among other functions (Levin 1973; Wagner et al. 2004; Silva et al. 2005). The parameters of distribution, morphology and exudate composition of secretory trichomes are important for the understanding of the function of these structures. Only the present study and two studies conducted on Ficus (Machado et al. 2013; Souza et al. 2015) have been performed within this context.

The phenolic compounds present in the secretory trichomes of Artocarpus heterophyllus and Maclura tinctora, for example, may have a double function, i.e., protection against herbivores or protection against ultraviolet radiation (Harborne 1989; Pourcel et al. 2006; Carvalho et al. 2007; Haslam 2007; Castro \& Demarco 2008). In Moraceae, phenolic-secreting trichomes have been reported only for Ficus species, for which the authors inferred these same functions for the trichomes (Souza et al. 2015). In contrast, the polysaccharides observed in the exudate of secretory trichomes of Artocarpus heterophyllus, Dorstenia cayapia, Maclura tinctoria and Sorocea bonplandii may act in the protection against organ desiccation and in organ lubrication, as suggested for the secretory trichomes of Leonotis leonurus (Lamiaceae, Ascenção \& Pais 1998) and Ficus enormis (Moraceae, Machado et al. 2013). In addition to the secretory trichomes of Ficus enormis, the trichomes of Brosimum gaudichaudii (Jacomassi et al. 2007) also contain polysaccharides and lipids. The lipids and alkaloids detected in the trichomes of all species studied may be related to mechanisms of protection against herbivores and pathogens (Levin 1973; Harborne 1989; Maffei 2010; Chern et al. 2013), while the proteins detected do not compose the exudate and may be related to the high metabolic activity of these structures since the enzymes responsible for the synthesis of metabolites are abundant in active secretory structures (Fahn 1979).

It is interesting to note the greater quantity of alkaloids in the trichomes studied compared to the other substances detected. Surprisingly this is the first report of alkaloids in trichomes of Moraceae representatives. This is due more to the lack of tests to detect alkaloids on the trichome exudate in Moraceae, than to the absence of this substance which is considered recurrent in urticalean rosids (Levin 1976). Therefore, for Moraceae species and Cannabis sativa (Cannabaceae), trichomes and laticifers are the structures responsible for the secretion of alkaloids (present study; Furr \& Mahlberg 1981; Lanyon et al. 1981; Kim \& Mahlberg 1997; Konno et al. 2006; Araújo et al. 2014), whereas in Urticaceae alkaloids have been identified in urticant emergences (Thurston \& Lersten 1969).

In addition to protecting and lubricating the organs, the secretory trichomes may act on the attraction of pollinators and dispersers (Fahn 2000; 2002), depending on their location and on the nature of the content produced. Secretory trichomes present in floral organs can produce nectar, volatile and non-volatile oil or sticky substances (Vogel \& Machado 1991; Lopes et al. 2002; Moyano et al. 2003; Marinho et al. 2014), contributing to the pollination of the species and its reproductive success. This does not seem to be the case for the floral trichomes of $S$. bonplandii since their morphology and secretory content are similar to those of the secretory trichomes of leaves. On the other hand, the exclusive presence of polysaccharides in the subcuticular space of the trichomes of D. cayapia pistillate inflorescences indicates that these structures may exert different functions in its reproductive organs, such as in the adhesion of pollen grains. Moreover, it is important to consider that only more specific chemical tests of these trichomes would permit us to state whether their exudate is the same for all organs or differs between them, thus permitting a more objective inference about their functions (see Marinho et al. 2016). 
The lipid compounds observed on the anticlinal walls of the trichome peduncles have been previously reported for secretory trichomes and seem to act on the directing of symplastic transport among the basal cells, the peduncle cells and the head, preventing the reflux of toxic substances from the cells of the head to other plant tissues (Fahn 1979; Castro \& Machado 2012).

Although various reports of secretory trichomes are available for Moraceae (Shah \& Kachroo 1975; Gangadhara \& Inamdar 1977; Wu \& Kuo-Huang 1997; Jacomassi \& Machado 2003; Jacomassi et al. 2007; Munir et al. 2011; Duarte et al. 2012), these studies were limited to leaf trichomes and dealt only with morphological aspects, with rare reports about the nature of the content of these trichomes in their representative species. Thus, the present study contributes to the knowledge of the distribution, morphology and chemical nature of the exudate of secretory trichomes of Moraceae, especially the floral ones. The study of the exudate of these trichomes permitted us to infer their probable ecological functions for the group. Such a wealth of different metabolite classes in the trichome exudate must be highlighted and provokes us to conduct ultrastructural studies of the dynamics of secretion, relating the organelles to the various compounds produced.

\section{Acknowledgements}

We thank Edimárcio S. Campos, Aline Rejane S. Gualberto (Botany Laboratory, FCFRP/USP), José Augusto Maulin (LMME, FMRP/USP) and Rodrigo F. Silva (Chemistry Department, FFCLRP/USP) for technical assistance and to Elettra Greene for the English revision. This study was funded by Fapesp (process number 2014/07453-3). B. N. Schnetzler is indebted to University of São Paulo (PróReitoria de Graduação), C. R. Marinho is indebted to Fapesp (process number 2013/21794-5) and S. P. Teixeira to CNPq (process number 303493/2015-1) for their fellowships.

\section{References}

Araújo LM. 2008. Biologia reprodutiva de espécies raras e ameaçadas de extinção de Dorstenia L. (Moraceae). PhD Thesis, Universidade Federal de Viçosa, Brazil.

Araújo ND, Coelho VPM, Ventrella MC, Agra MF. 2014. Leaf anatomy and histochemistry of three species of Ficus sect. Americanae supported by light and electron microscopy. Microscopy and Microanalysis 20: 296-304.

Ascenção L, Pais MS. 1998. The leaf capitate trichomes of Leonotis leonurus: histochemistry, ultrastructure and secretion. Annals of Botany 81: 263-271.

Carvalho JCT, Gosmann G, Schenkel EP. 2007. Compostos fenólicos simples e heterosídicos. In: Simões CMO, Schenkel EP, Gosmann G, Mello JCP, Mentz LA, Petrovick PR. (orgs.) Farmacognosia: da planta ao medicamento. 6th. edn. Porto Alegre, Editora UFRGS; Florianópolis, Editora da UFSC. p. 519-535.

Castro MM, Demarco D. 2008. Phenolic compounds produced by secretory structures in plants: a brief review. Natural Product Communications 3: $1273-1284$.
Castro MM, Machado SR. 2012. Células e tecidos secretores. In: Appezzatoda-Glória B, Carmello-Guerreiro SM. (eds.) Anatomia Vegetal. 3rd. edn. Viçosa, Editora UFV. p. 179-203.

Chern LY, Shukor MY, Muse R. 2013. Monoterpenes in plants - a mini review. Asian Journal of Plant Biology 1: 15-19.

Clement WL, Weiblen GD. 2009. Morphological evolution in the mulberry family (Moraceae). Systematic Botany 34: 530-552.

Dickison WC. 2000. Integrative plant anatomy. New York/ London/ Tokyo, Academic Press.

Duarte MR, Gomes JB, Santos RH, Yano M. 2012. Caracteres microscópicos de folha de Maclura tinctoria (L.) D. Don ex Steud., Moraceae. Visão Acadêmica, Curitiba 13: 4-15.

Esau K. 1974. Anatomia das plantas com sementes. São Paulo, Edgard Blucher.

Fahn A. 1979. Secretory tissues in plants. London/ New York/ San Francisco, Academic Press.

Fahn A. 2000. Structure and function of secretory cells. Advanced Botanical Research 31: 37-75.

Fahn A. 2002. Functions and location of secretory tissues in plants and their possible evolutionary trends. Israel Journal of Plant Sciences 50: S59-S64.

Filho CV, Yunes AR. 1998. Estratégias para obtenção de compostos farmacologicamente ativos a partir de plantas medicinais. Conceitos sobre modificação estrutural para otimização da atividade. Química Nova 21: 99-105.

Furr M, Mahlberg PG. 1981. Histochemical analyses of laticifers and glandular trichomes in Cannabis sativa. Journal of Natural Products 44: 153-159.

Gangadhara M, Inamdar JA. 1977. Trichomes and stomata, and their taxonomic significance in the Urticales. Plant Systematics and Evolution 127: 121-137.

Gobbo-Neto L, Lopes PN. 2007. Plantas medicinais: fatores de influência no conteúdo de metabólitos secundários. Química Nova 30: 374-381.

Harborne JB. 1989. Recent advances in chemical ecology. Natural Product Reports 16: 509-523.

Haslam E. 2007. Vegetable tannins - lessons of a phytochemical lifetime. Phytochemistry 68: 2713-2721.

Jacomassi E, Machado SR. 2003. Características anatômicas de espinheirasanta (Maytenus ilicifolia Mart. ex Reissek e Maytenus aquifolia Mart.) e mata-olho (Sorocea bonplandii (Baill.) Burg. Lanj. \& Boer.) para o controle de qualidade da matéria-prima. Revista Brasileira de Plantas Medicinais 6: 84-96.

Jacomassi E, Moscheta IS, Machado SR. 2007. Morfoanatomia e histoquímica de Brosimum gaudichaudii Trécul (Moraceae). Acta Botanica Brasilica 21: 575-597.

Jacomassi E, Moscheta IS, Machado SR. 2010. Morfoanatomia e histoquímica de órgãos reprodutivos de Brosimum gaudichaudii (Moraceae). Revista Brasileira de Botânica 33: 115-129.

Jagtap UB, Bapat VA. 2010. Artocarpus: A review of its traditional uses, phytochemistry and pharmacology. Journal of Ethnopharmacology 129: 142-166.

Jensen WA. 1962. Botanical histochemistry: Principles and practice. San Francisco, W.H. Freeman and Co.

Johansen DA. 1940. Plant microtechnique. New York, McGraw-Hill Book Co. Inc.

Judd WS, Campbell CS, Kellogg EA, Stevens PF. 2009. Sistemática vegetal, um enfoque filogenético. 3rd. edn. Porto Alegre, Artmed.

Karnovsky MJ. 1965. A formaldehyde-glutaraldehyde fixative of light osmolality for use in electron microscopy. Journal of Cell Biology 27: 137-138.

Kim E, Mahlberg PG. 1997. Immunochemical localization of tetrahydrocannabinol (THC) in cryofixed glandular trichomes of Cannabis (Cannabaceae). American Journal of Botany 84: 336-342.

Konno K, Ono H, Nakamura M, et al. 2006. Mulberry latex rich in antidiabetic sugar-mimic alkaloids forces dieting on caterpillars. PNAS 103: 1337-1341.

Lanyon VS, Turner JC, Mahlberg PG. 1981. Quantitative analysis of cannabinoids in the secretory product from capitate-stalked glands of Cannabis sativa L. (Cannabaceae). Botanical Gazette 142: 316-319. 
Levin DA. 1973. The role of trichomes in plant defense. The Quarterly Review of Biology 48: 3-15.

Levin DA. 1976. Alkaloid-bearing plants: an ecogeographic perspective. The American Naturalist 110: 261-284.

Lillie RD. 1965. Histopathologic technic and practical histochemistry. 3rd. edn. New York/ Toronto/ Sydney/ London, McGraw-Hill Book Company.

Lopes AV, Vogel S, Machado IC. 2002. Secretory trichomes, a substitutive floral nectar source in Lundia A. DC. (Bignoniaceae), a genus lacking a functional disk. Annals of Botany 90: 169-174.

Lorenzi H, Matos FJA. 2002. Plantas medicinais no Brasil: nativas e exóticas cultivadas. Nova Odessa, Instituto Plantarum.

Machado AFP, Souza AM, Leitão CAE. 2013. Secretory structures at syconia and flowers of Ficus enormis (Moraceae): A specialization at ostiolar bracts and the first report of inflorescence colleters. Flora 208: 45-51.

Maffei ME. 2010. Sites of synthesis, biochemistry and functional role of plant volatiles. South African Journal of Botany 76: 612-631.

Marinho CR, Oliveira RB, Teixeira SP. 2016. The uncommon cavitated secretory trichomes in Bauhinia s.s. (Fabaceae): the same roles in different organs. Botanical Journal of the Linnean Society 180: 104122.

Marinho CR, Souza CD, Barros TC, Teixeira SP. 2014. Scent glands in legume flowers. Plant Biology 16: 215-226.

Martínez AM. 2008. Aportes a la anatomía foliar de Artocarpus communis, A. heterophyllus y Brosimum alicastrum (Moraceae). Revista del Jardín Botánico Nacional 28: 201-203.

Metcalfe CR, Chalk L. 1950. Anatomy of the Dicotyledons. Vol. II. Oxford, Clarendon Press.

Moyano F, Cocucci A, Sérsic A. 2003. Accessory pollen adhesive from glandular trichomes on the anthers of Leonurus sibiricus L. (Lamiaceae). Plant Biology 5: 411-418.

Munir M, Khan MA, Ahmed M, et al. 2011. Foliar epidermal anatomy of some ethnobotanically important species of wild edible fruits of northern Pakistan. Journal of Medicinal Plants Research 5: 5873-5880.

O'Brien TP, Feder N, McCully ME. 1964. Polychromatic staining of plant cell walls by toluidine blue O. Protoplasma 59: 368-373.

Pearse AGE. 1985. Histochemistry: theoretical and applied. 4th. edn. Edinburgh, C. Livingstone.

Pourcel L, Routaboul J, Cheynier V, Lepiniec L, Debeaujon I. 2006. Flavonoid oxidation in plants: from biochemical properties to physiological functions. Trends in Plant Science 12: 29-36.
Press MC. 1999. The functional significance of leaf structure: a search for generalizations. New Phytologist 143: 213-219.

Shah AM, Kachroo P. 1975. Comparative anatomy in Urticales: I. The trichomes in Moraceae. Journal of the Indian Botanical Society 54: 138-153.

Silva LM, Alquini Y, Cavallet VJ. 2005. Inter-relações entre anatomia vegetal e produção vegetal. Acta Botanica Brasilica 19: 183-194.

Smith FH, Smith EC. 1942. Anatomy of the inferior ovary of Darbya. American Journal of Botany 29: 464- 471.

Souza CD, Pereira RAS, Marinho CR, Kjellberg F, Teixeira SP. 2015. Diversity of fig glands is associated with nursery mutualism in fig trees. American Journal of Botany 102: 1-14.

Souza LA, Rosa SM. 2005. Morfo-anatomia do fruto em desenvolvimento de Sorocea bonplandii (Baill.) Burger, Lanjow \& Boer (Moraceae). Acta Scientiarum. Biological Sciences 27: 423-428.

Sytsma KJ, Morawetz J, Pires JC, et al. 2002. Urticalean Rosids: circumscription, rosid ancestry, and phylogenetics based on rbcL, trnL-F, and ndhF sequences. American Journal of Botany 89: 15311546.

The Plant List.2013. Version 1.1. Published on the Internet; http://www. theplantlist.org/ 1 Jan. 2016.

Thurston LE, Lersten NR. 1969. The morphology and toxicology of plant stinging hairs. Botanical Review 35: 393-412.

Tobe H, Takaso T. 1996. Trichome micromorphology in Celtidaceae and Ulmaceae (Urticales). Acta Phytotaxonomica et Geobotanica 47: 153-168.

Ustulin M, Figueiredo BB, Tremea C, et al. 2009. Plantas medicinais comercializadas no Mercado Municipal de Campo Grande-MS. Revista Brasileira de Farmacognosia 19: 805-813.

Vidal BC. 1970. Dichroism in collagen bundles stained with xylidinePonceau 2R. Annales d'Histochimie 15: 289-296.

Vogel S, Machado IC. 1991. Pollination of four sympatric species of Angelonia (Scrophulariaceae) by oil-collecting bees in NE Brazil. Plant Systematics and Evolution 178: 153-178.

Wagner GJ, Wang E, Shepherd RW. 2004. New Approaches for studying and exploiting an old protuberance, the plant trichome. Annals of Botany 93: 3-11.

Wu C, Kuo-Huang L. 1997. Calcium crystals in the leaves of some species of Moraceae. Botanical Bulletin of Academia Sinica 38: 97-104. 